\title{
Variation in Chemical Composition of Guava Leaves (Psidium guajava L.) as Affected by Position in the Terminals ${ }^{1}$
}

\author{
Saulo J. Rodríguez ${ }^{2}$ \\ INTRODUCTION
}

Leaf analysis has become a powerful tool in mineral-nutrition research with horticultural crops, not only to determine response to different nutrients, but also for diagnostic techniques in making fertilizer recommendations and assessing deficiency symptoms. Recently, Kenworthy (2) ${ }^{3}$ and Chapman (1), separately, presented guides for leaf sampling in horticultural crops, covering not only vegetable but fruit crops as well.

For guava trees Kenworthy suggested that the third pair of leaves be taken from nonfruiting terminals 2 to 3 weeks after the flush has stopped growth. If there was not a characteristic flush of growth, the samples should be collected from nonfruiting terminals during the main flowering period. The entire sixth or seventh leaf from the apex should be used (2).

No information is available on guava-leaf analysis. Since age is an important factor affecting the chemical composition of the leaves (3), we tried to determine the effect of age on leaf nutrients by chemically analyzing leaves in different positions on nonfruiting and fruiting terminals.

\section{PROCEDURE}

Three uniform guava trees growing at the Gurabo Substation were selected for the work. These trees were not receiving any specific fertilizer treatment.

In each tree, 10 fruiting and 10 nonfruiting terminals in active growth were marked separately representing all positions on the tree. Leaf samples were collected from each terminal starting at its apex and advancing downward to where it joined the main stem. The first unfolded leaf was regarded as in the first position, and thereafter each succeeding node was considered a separate position, and each was numbered in sequence. The leaves from each position on a terminal were composited with leaves from the same position on other terminals from each tree. Nonfruiting and fruiting terminals were kept separate for each tree. All terminals were actively growing when the samples were collected.

The samples were sent to the Central Analytical Laboratory of the

${ }^{1}$ Contribution from the Gurabo Substation, University of Puerto Rico, Río Piedras, P.R.

${ }^{2}$ Associate Horticulturist, Gurabo Substation.

${ }^{3}$ Italic numbers in parenthesis refer to Literature Cited, pp. 258-9. 
Station for phosphorus and nitrogen determinations. The rest of the nutrients were determined spectrographically at the Plant Analysis Laboratory of the Horticulture Department, Michigan State University (2).

The data were not processed statistically except for taking the arithmetic mean for each nutrient, because insufficient replications were available.

\section{RESULTS AND DISCUSSION}

The results obtained are presented in tables 1 and 2, but can be more clearly appreciated as graphically presented in figs. 1,2, and 3. The fruiting terminals generally had fewer attached leaves than nonfruiting ones and therefore the data were limited to 8 positions as compared with 12 for nonfruiting terminals.

TABLE 1.-The effect of age on the mineral composition of guava leaves of fruiting branches ${ }^{1}$

\begin{tabular}{|c|c|c|c|c|c|c|c|c|c|c|c|c|}
\hline \multirow{2}{*}{$\begin{array}{l}\text { Leaf } \\
\text { No. }\end{array}$} & \multicolumn{12}{|c|}{ Mineral composition of guava leaves on a dry-weight basis } \\
\hline & $\mathrm{N}$ & $P$ & $\mathrm{~K}$ & $\mathrm{Ca}$ & $\mathrm{Mg}$ & $\mathrm{Na}$ & Mn & $\mathrm{Fe}$ & $\mathrm{Cu}$ & B & $\mathrm{Zn}$ & $\mathrm{Al}$ \\
\hline & Percent & Percent & Percent & Percent & Percent & P.p.m. & P.p.m. & P.p.m. & P.p.m. & P.p.m. & P.p.m. & P.p.m. \\
\hline 1 & 2.76 & 0.335 & 2.43 & 0.80 & 0.28 & 496 & 24 & 70 & 21.2 & 76.0 & 27.0 & 58.5 \\
\hline 2 & 2.62 & .294 & 2.64 & .86 & .36 & 532 & 28 & 95 & 18.4 & 4 & 32.5 & 49.0 \\
\hline 3 & 2.47 & .218 & 1.54 & 1.18 & .57 & 492 & 43 & 92 & 18.8 & 39.3 & 26.0 & 70.5 \\
\hline 4 & 2.29 & .186 & 1.04 & 1.30 & .64 & 793 & 54 & 125 & 19.8 & 39.3 & 22.5 & 103.0 \\
\hline 5 & 2.32 & .169 & .96 & 1.30 & .68 & 794 & 60 & 132 & 23.4 & 40.0 & 24.5 & 119. \\
\hline 6 & 2.10 & .149 & .81 & 1.58 & .78 & 1,079 & 73 & 176 & 28.1 & 44.2 & 27.5 & 160.5 \\
\hline 7 & 1.96 & .177 & .78 & 1.77 & .86 & 1,568 & 82 & 253 & 29.9 & 56.6 & 24.0 & 213.0 \\
\hline 8 & 1.70 & .169 & .46 & 2.60 & 1.09 & 1,402 & 101 & 335 & 34.4 & 52.5 & 31.0 & 232.0 \\
\hline
\end{tabular}

${ }^{1}$ Mean values for 3 trees.

As expected, the mineral composition of the leaves appears to change progressively during early growth, maturity, and senescence. The phosphorus content appears to decrease at a rapid rate until a leveling off occurs at the sixth or seventh position on both nonfruiting and fruiting terminals. The same is true of nitrogen, but not at the same rate and at the same position. Since younger tissues are higher in proteins, and since both nitrogen and phosphorus are protein components, there is a greater accumulation in younger than in old tissues.

Leaf potassium increased slightly at the beginning, reaching a maximum in the second position which corresponds to the first fully expanded leaf. Thereafter there was a constant decrease in content and a relative leveling off from the sixth leaf downward in nonfruiting terminals. The leveling off occurred sooner in the fruiting than in nonfruiting terminals.

After a minor decrease which occurred in the first fully expanded leaf of nonfruiting terminals, the calcium content increased with age and leveled 
off in the third and fifth leaves of fruiting and nonfruiting terminals, respectively. The same overall trend was seen with magnesium. The inverse relationship of the three major cations with age or leaf position in the plant can be clearly observed in the graphical representations. This same nutrient balance relationship has been observed by Shear et al., working on tung-tree nutrition (5).

The secondary and minor elements generally tended to increase with age of the leaves. The sodium content was quite variable both in fruiting:

TABLE 2.-The effect of age on the mineral composition of guava leaves of nonfruiting branches ${ }^{1}$

\begin{tabular}{|c|c|c|c|c|c|c|c|c|c|c|c|c|}
\hline \multirow{2}{*}{$\begin{array}{l}\text { Leaf } \\
\text { No. }\end{array}$} & \multicolumn{12}{|c|}{ Mineral composition of guava leaves on a dry-weight basis } \\
\hline & $\mathrm{N}$ & P & $\mathrm{K}$ & $\mathrm{Ca}$ & $\mathrm{Mg}$ & $\mathrm{Na}$ & $\mathrm{Mn}$ & $\mathrm{Fe}$ & $\mathrm{Cu}$ & B & $\mathrm{Z}_{n}$ & $\mathrm{Al}$ \\
\hline & Percent & Percent & Percent & Percent & Percent & P.p.m. & P.p.m. & P.p.m. & P.p.m. & P.p.m. & P.p.m. & P.p.m. \\
\hline 1 & 2.77 & 0.338 & 2.50 & 0.81 & 0.27 & 382 & 21 & 119 & 19.3 & 70.9 & 28.3 & 47.7 \\
\hline 2 & 2.70 & .313 & 2.64 & .65 & .36 & 337 & 24 & 75 & 18.4 & 47.3 & 30.0 & 53.7 \\
\hline 3 & 2.49 & .245 & 1.84 & 1.14 & & 463 & 36 & 51 & 17.5 & 33.4 & 25.0 & 60.0 \\
\hline 4 & 2.37 & .214 & 1.14 & 1.49 & .68 & 701 & 48 & 72 & 18.4 & 43.2 & 28.9 & 91.3 \\
\hline 5 & 2.29 & .202 & 06 & 1.63 & .74 & 682 & 57 & 146 & 20.2 & 46.3 & 29.7 & 112.3 \\
\hline 6 & 2.24 & .183 & & 1.68 & .79 & 899 & 63 & 87 & 17.5 & 51.6 & 7 & 115.3 \\
\hline 7 & 2.15 & .172 & .65 & 1.83 & .83 & 927 & 70 & 204 & 23.1 & 52.1 & 30.7 & 165. \\
\hline 8 & 1.95 & .174 & .62 & 2.01 & .86 & 1,182 & 81 & 197 & 31.9 & 47.9 & 35.0 & 178.0 \\
\hline 9 & 1.84 & & .45 & 2.34 & .94 & 1,008 & 87 & 236 & 27.0 & 56.0 & 34.7 & 210.3 \\
\hline 10 & 1.91 & .173 & .46 & 2.41 & .96 & 1,079 & 93 & 249 & 27.9 & 44.6 & 35.0 & 240.0 \\
\hline 11 & 1.82 & .169 & .48 & 2.54 & .96 & 1,084 & 103 & 211 & 27.9 & 43.2 & 36.5 & 245.0 \\
\hline 12 & 1.68 & .186 & .43 & 2.77 & 1.02 & 1,296 & 104 & 123 & 31.9 & 45.2 & 45.0 & 184.0 \\
\hline
\end{tabular}

${ }^{1}$ Mean values for 3 trees.

and nonfruiting terminals, but there was a definite tendency to increase with age.

The manganese content increased quite regularly with age in both fruiting and nonfruiting terminals. The iron content was quite variable in nonfruiting terminals, while in fruiting terminals there was a definite increase with age. Copper decreased at the beginning in both fruiting and nonfruiting terminals, with a definite increase in fruiting terminals from the second leaves downward. In nonfruiting terminals, there was a slight increase from the third to the fifth leaf, with a decrease in the sixth. From the sixth to the eighth there was a high increase. Copper decreased in the ninth leaf, while a leveling off occurred in the tenth and eleventh leaves, with a further increase in the twelfth.

The big changes in boron content occurred in the young leaves of nonfruiting and fruiting terminals. There was a decrease from the terminal 
leaf to the third leaf. From the third to the seventh leaves in nonfruiting terminals there was an increase in boron content with a subsequent decrease and increase in the eighth, ninth, and tenth positions, respectively.
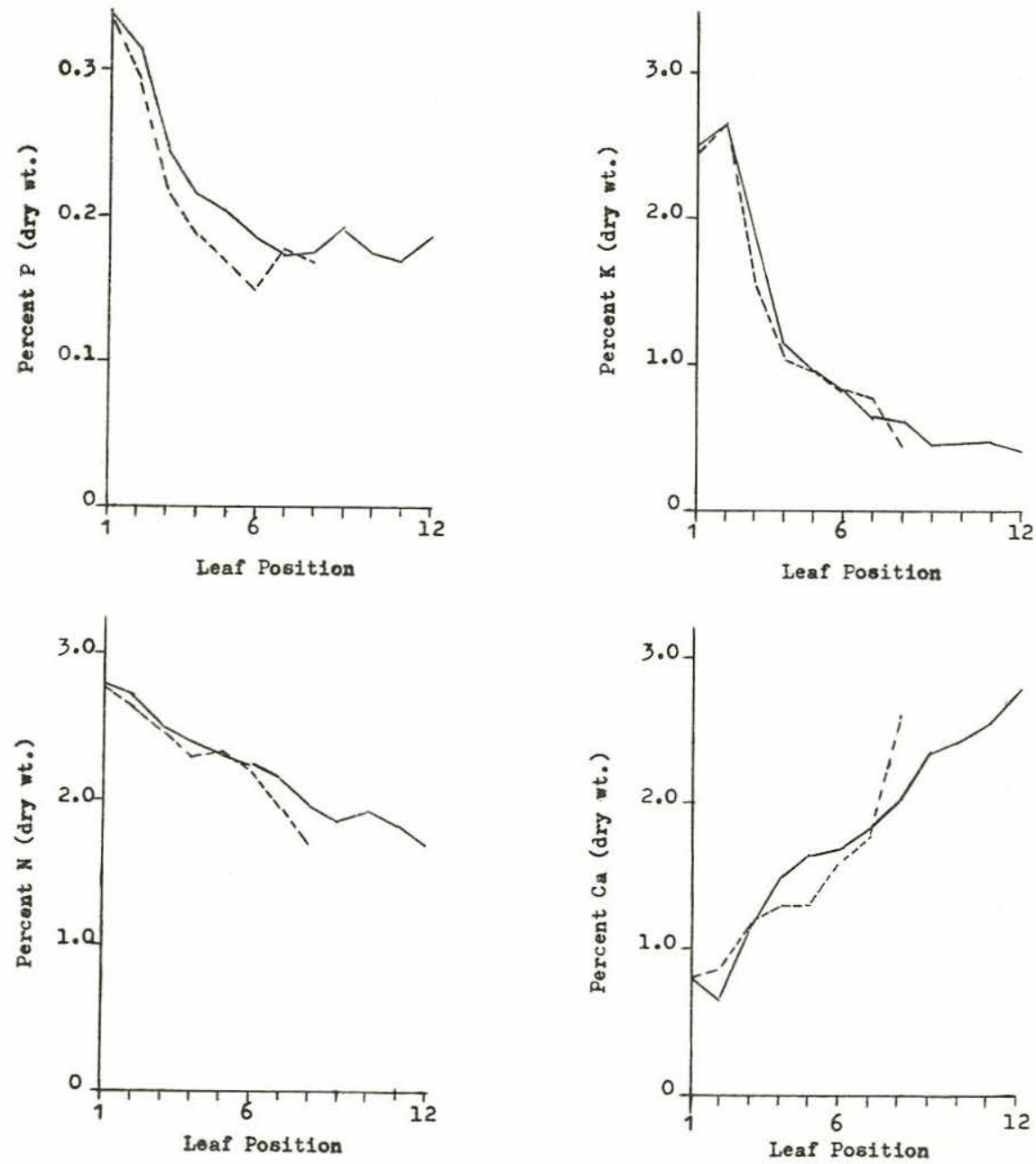

Fig. 1.-Effects of leaf position on $\mathrm{P}, \mathrm{K}, \mathrm{N}$, and Ca contents (percentage dry weight) of guava leaves. Unbroken lines represent nonfruiting, and broken lines fruiting terminals.

Zine content did not change as much with age as that of other nutrients. The changes were staggered both in nonfruiting and fruiting terminals. There was some small decrease in aluminium content at the beginning, 

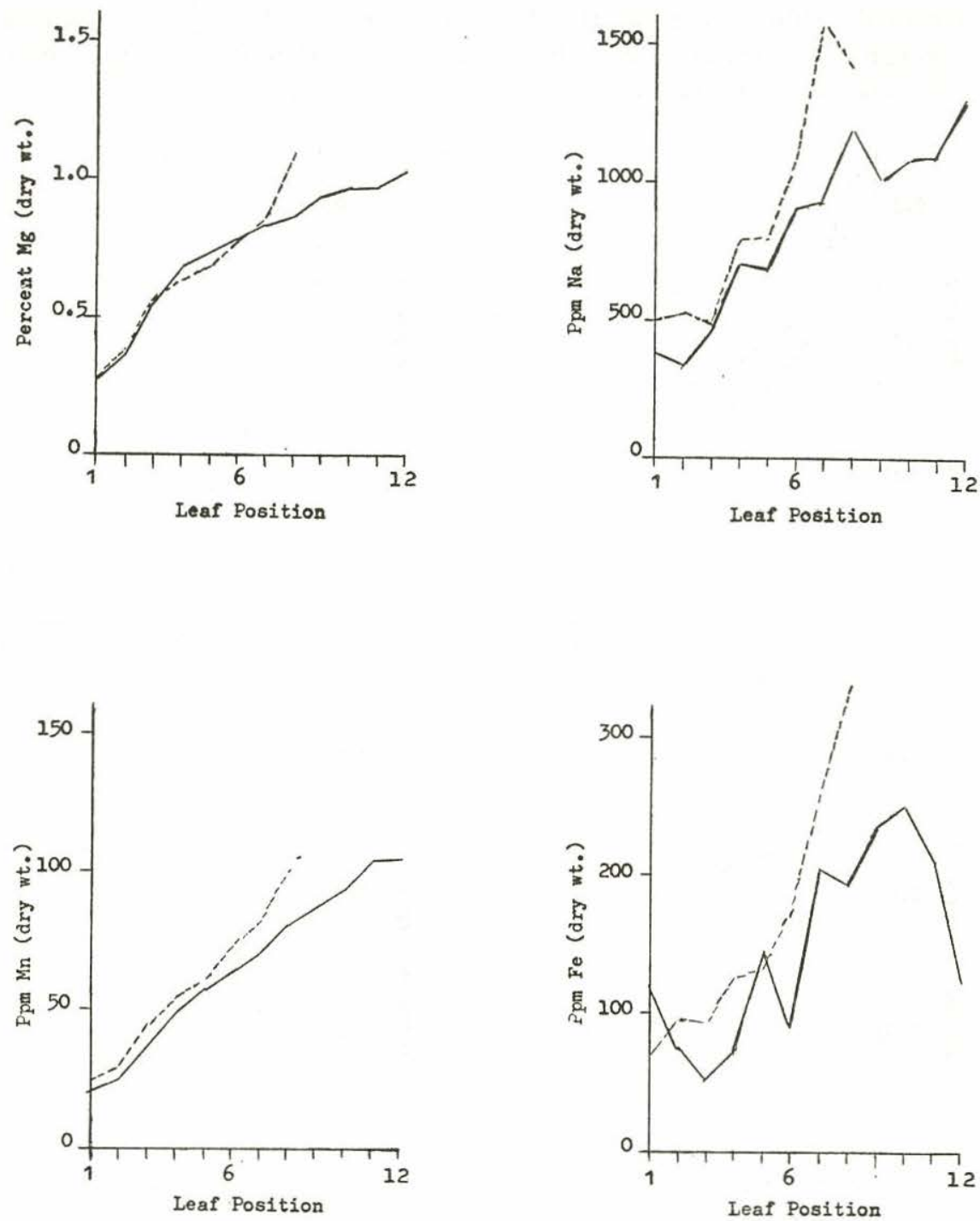

FIG. 2.-Effects of leaf position on $\mathrm{Mg}, \mathrm{Na}, \mathrm{Mn}$, and $\mathrm{Fe}$ contents, percentage dry weight or p.p.m., as indicated, of guava leaves. Unbroken lines represent nonfruiting, and broken lines fruiting terminals.

with a tendency to increase with age up to the eighth leaf in the fruiting terminals and the eleventh leaf in the nonfruiting ones. In the last case the last leaf showed a decrease in content.

Although the results obtained were somewhat variable, some conclusions 

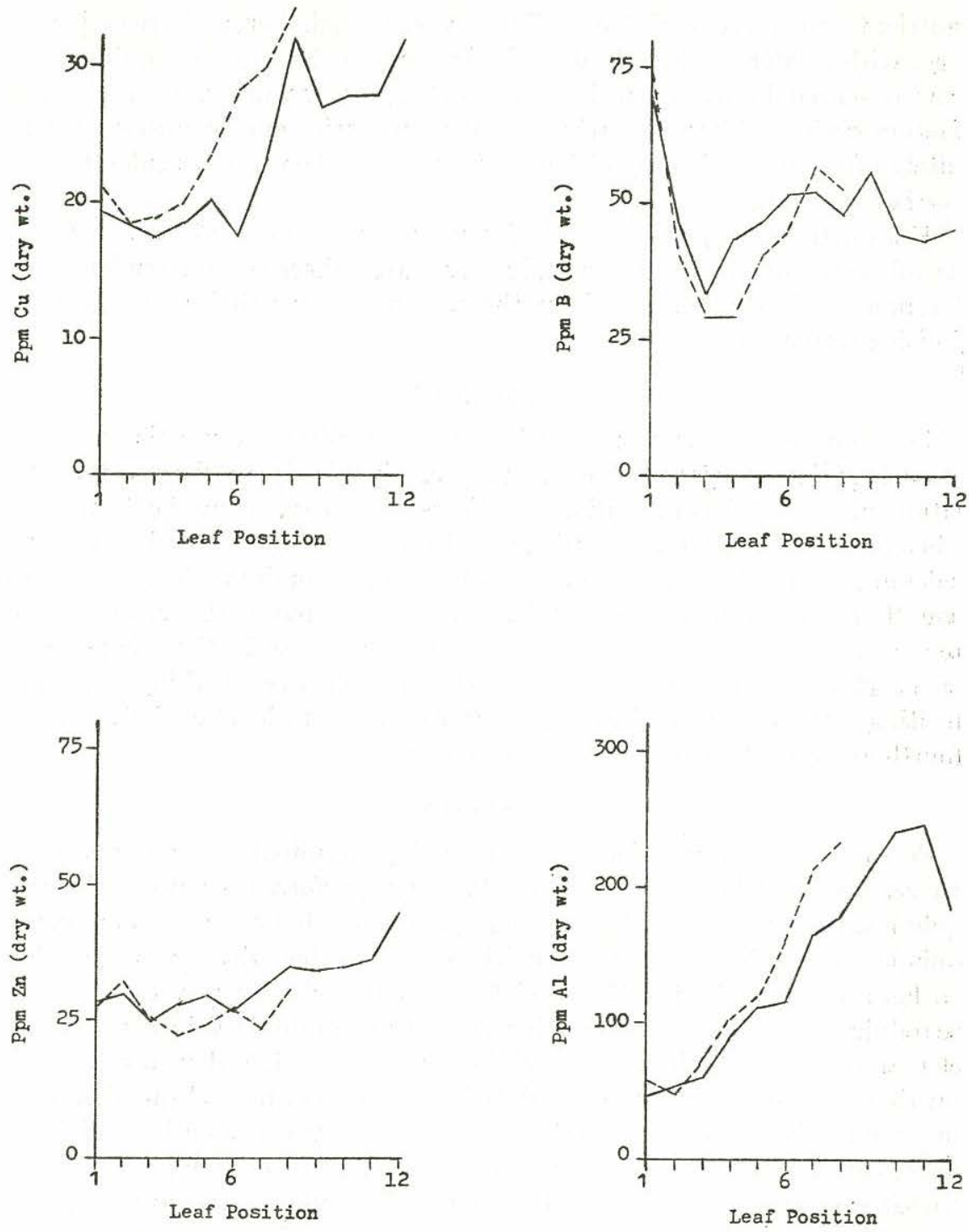

FIG. 3.-Effects of leaf position on $\mathrm{Cu}, \mathrm{B}, \mathrm{Zn}$, and $\mathrm{Al}$ contents (p.p.m.) of guava leaves. Unbroken lines represent nonfruiting, and broken lines fruiting terminals.

were arrived at which can serve as guides in future nutritional research with guava trees. Definitely, leaf nitrogen, potassium, and phosphorus are lower in older than in younger leaves, while calcium, magnesium, manganese, sodium, and aluminium tend to increase with age. The other 
nutrients are more variable in the leaves, though boron decreased with age, with a later increase in the middle position. Not too much difference was observed between fruiting and nonfruiting terminals. Undoubtedly, factors such as dilution, leaching, and interrelationship of nutrients definitely affect the leaf composition, and must be taken into consideration in further research.

Kenworthy's suggestion for leaf sampling in guavas $(3)$ is somewhat corroborated by the results since, in most cases, there is some tendency for leveling off in composition from the fourth to seventh leaf of the nonfruiting terminals.

\section{SUMMARY}

Leaf samples taken from fruiting and nonfruiting terminals of guava trees (Psidium guajava L.) were analyzed chemically to observe the variation in chemical composition as affected by position in the terminals. Phosphorus, potassium, and nitrogen decreased definitely with age while calcium, magnesium, manganese, sodium, and aluminum increased with age. The other nutrients determined were somewhat variable, but boron tended to decrease at the beginning with an increase in the middle positions. Not too much difference was observed between fruiting and nonfruiting terminals. Chemical compositions tended to level off between the fourth and seventh positions in the terminals.

\section{RESUMEN}

Se tomaron muestras foliares de las ramas terminales, fructíferas y no fructíferas, de árboles de guayaba (Psidium guajava L.) para analizarlas químicamente y observar la variación que pudiera haber en su composición química, según los elementos nutritivos fueran afectados por su posición en las ramas terminales. Tanto el fósforo como el potasio y el nitrógeno se redujeron definitivamente con la edad, mientras que el calcio, el magnesio, el manganeso, el sodio y el aluminio aumentaron. Los demás elementos nutritivos mostraron bastante variabilidad, siendo el boro el que demostró una tendencia a disminuir al principio y luego a aumentar en las posiciones intermedias. No hubo una variación marcada entre las ramas terminales fructíferas y las no fructíferas. La composición química tendió a nivelarse entre la cuarta y séptima posición en las ramas terminales.

\section{LITERATURE CITED}

1. Chapman, H. D., Técnicas propuestas para la extracción y nutrición de las muestras foliares con vista a determinar el estado nutritivo de algunos productos agrícolas, hortícolas y arbustivos, Revista de la Potasa, Instituto Internacional de la Potasa, Berna, Suiza, December-January, 1964-65. 
2. Kenworthy, A. L., Photoelectric Spectrometer Analysis of Plant Materials, Michigan State University, Report presented at Annual Meeting of A.S.H.S., Stillwater, Okla., 1960.

3. - - Fruit, Nut, and Plantation Crops; Deciduous and Evergreen; A Guide for Collecting Foliar Samples for Nutrient-Element Analysis, Horticulture Department, Michigan State University, East Lansing, Mich., June 1964.

4. Reuther, Walter, E., Plant Analysis, and Fertilizer Problems, Pub. 8, Amer. Inst. of Biol. Sci. Washington 6, D.C., 1961.

5. Shear, C. B., Crane, H. L., and Myer, A. T., Nutrient element balance, a fundamental eoncept in plant nutrition. Proc. Amer. Soc. Hort. Sci. 47: 239-48, 1946. 